\title{
A Review of the Welfare Impact on Pinnipeds of Plastic Marine Debris
}

\author{
Andy Butterworth * \\ Clinical Veterinary Science, University of Bristol Veterinary School, Bristol, UK
}

Uncounted, and usually unobserved, numbers of pinnipeds find themselves entangled in lost fishing gear, monofilament line, nets, rope, plastic packaging in the ocean or on the shoreline. These animals may carry debris wrapped around themselves for long periods, and often die as a result, sometimes from deep chronic wounds. The pinniped species most affected by this modern and manmade phenomenon are fur seals, monk seals, and California sea lions, and to a lesser extent gray, common, and monk seals. Entanglement rates described range up to $7.9 \%$ of local populations annually, and the common entangling materials; packing bands, fragments of lost net, rope, monofilament line, fishery flashers and lures, long-line fishing gear, hooks and line, and bait hooks are discussed. Awareness of this issue is increasing, and local action is reported to have made measurable differences in entanglement rates, however, plastic material in the ocean is likely to be long lived, and will leave many entangled pinnipeds unreported and result in a hidden and potentially significant effect on wild animal welfare.

\section{OPEN ACCESS}

Edited by:

Lyne Morissette,

$M$ - Expertise Marine, Canada

Reviewed by:

Julia Ann Jabour,

University of Tasmania, Australia Christian T. K.-H. Stadtlander,

Independent Researcher, USA

*Correspondence:

Andy Butterworth

andy.butterworth@bris.ac.uk

Specialty section: This article was submitted to Marine Affairs and Policy, a section of the journal Frontiers in Marine Science

Received: 06 April 2016 Accepted: 04 August 2016 Published: 18 August 2016

Citation: Butterworth A (2016) A Review of the Welfare Impact on Pinnipeds of Plastic Marine Debris. Front. Mar. Sci. 3:149. doi: 10.3389/fmars.2016.00149
Keywords: welfare, pinnipedia, marine debris, seals, entanglement

\section{INTRODUCTION}

Uncounted, and usually unobserved, numbers of the animals that live in the oceans find themselves snared, trapped, or entangled in lost fishing gear, monofilament line, nets, rope, plastic packaging, packing bands from crates, or become hooked on discarded fishing gear, or ingest human marine debris. Seals, sea lions, and walrus (the pinnipeds), seem particularly susceptible to entanglement in marine debris-perhaps their exploratory natures may make this more likely, or perhaps they come upon plastic waste and rope on the shoreline to a greater extent than the other fully aquatic mammals? Pinnipeds, meeting with plastic, either in the sea, or on the shoreline, may carry debris wrapped around themselves, for long periods, and often die as a result-sometimes from horrible, chronic wounds (Dau et al., 2009). Although a wide range of the global species of seals can be affected by marine debris, some species are much more significantly affected than others. Based on the available literature, the key seal species affected by entanglement are monk seals, fur seals and California sea lions. Seals which become entangled or who ingest marine debris may be subjected to distress, pain, trauma, infection, skin, and muscle lesions, and compromised ability to move, to feed, and to carry out normal behaviors. For these reasons marine debris has the capacity to present a significant and global issue with respect to animal welfare, as well as to the more immediately apparent concerns regarding habitats and the quality of the marine environment. At present, there is little directed focus on marine debris in relation to animal welfare. Marine debris can:

- cause direct harm and profound welfare impacts on wild animals directly through entanglement and ingestion

- smother the seabed and disturb habitats-causing altered behaviors and population changes 
- can be a source of persistent chemical pollution in the oceanparticularly from plastics, which may result in direct toxicity effects in top predators if toxins accumulate in marine food

- marine debris can potentially transport invasive species between seas through flotation-and invasive species may alter the environment resulting in changed food and habitat availability

In this review published papers and reports are brought together which identify and describe entanglement and ingestion in seals and seal lions. Second, we assess the welfare impact on individual seal species of being entangled or of ingesting marine debris.

Marine debris is now found in all oceans of the globe, but its effects are not so uniformly spread, and the reporting of the effects of marine debris on animals is uneven, linked with the density of "observers" (including scientists), and also on the local cultural position with regard to interactions with marine animals. For this reason, there is almost no reporting of marine mammal entanglement in some parts of the world, but this may be a result of low reporting rates rather than low "incidence" rates. Harcourt et al. (1994) point out that most published entanglement incidence rates are likely to be conservative because they only register animals that come on shore, and do not account for those that die and are lost at sea. Moore et al. (2013) indicated that post-mortem examination of dead and live stranded pinnipeds can show the distribution of malicious human impacts, such as vessel collision, fishing gear entanglement and gunshot. These authors however, also note that delayed discovery, inaccessibility, logistics, and human safety concerns can limit accurate detection and reporting of the cause of death of "discovered" animals, and so under reporting of marine debris as a cause of death is likely to be an important factor in the estimation of the true numbers of animals affected.

There are significant variations in the geographical spread of research into the effects of marine debris on animals, and the Convention on Biological Diversity's 2012 report (CBD, 2012) highlights this imbalance by indicating the number of reports that it has reviewed regarding marine debris entanglement in a range of species (not just pinnipeds) from different regions: Americas (North and South (117), Australasia (56), Europe (52), Africa (12), Antarctic (7), Asia (6), Arctic (5). Some general comments on the variability of reporting of entanglement are made by Butterworth et al. (WSPA, 2012).

Estimates based on published reports can reflect only the areas where the reports were carried out, and the level of research and interest is not uniformly spread across the globe.

Estimates of animal entanglement and ingestion generally rely on reports of animals seen alive (or recently deceased), and so are likely to seriously underestimate the scale of the problem. If animals are affected and die unseen (as is likely to be common), then they are not reported. As Cole et al. (2006) say- "Our greatest concern remains the number of animals we never saw."

Even allowing for regional reporting biases, it is however apparent that some regions present a higher risk of entanglement and ingestion hazard, and so, it may well be that targeted action to reduce or ameliorate the local effects of marine debris on seals could focus resources in these areas. There are some apparent "hotspots" for seal entanglement; Western Coast USA-Fur seals, Sea lions; Eastern Coast Australia-Fur seals; Southern African coast-Fur seals; North sea-Gray seal.

\section{MARINE DEBRIS: BACKGROUND}

Norwegian explorer Thor Heyerdahl crossed the Atlantic Ocean in 1970, and at this time, he was sufficiently concerned about the litter and waste that he saw on the oceans to submit a report to the United Nations Conference on the Human Environment, held in Stockholm in 1972. The United Nations Environment Programme defines marine litter as "any persistent, manufactured or processed solid material discarded, disposed or abandoned in the marine and coastal environment," and the 2005 United Nations Environment Programme estimated that about 6.4 million tons of "litter" are disposed of in the seas and oceans each year. Today, estimates for the amount of marine debris vary, but it is thought that up to 300,000 items of litter and debris can be found, on average, per sq km of ocean surface (NRC, 2008). Marine debris includes plastics, rubber, metal, and glass, however, plastic in a myriad of forms has come to dominate marine litter, due to its long lifespan. The top ten marine debris items from 103,247,609 items collected 1989-2007 (ICC, 2008):

"Cigarettes/cigarette filters: 24.6\%, Bags (paper and plastic): 9.4\%, Caps/lids: 9.1\%, Food wrappers/containers: $8.9 \%$, Cups/plates/forks/knives/spoons: 7.2\%, Plastic beverage bottles (less than 2 l): $5.5 \%$, Glass beverage bottles: $4.8 \%$, Beverage cans: $4.6 \%$, Straws/stirrers: $4.4 \%$, Rope: $2.1 \%$ "

Wilcox et al. (2016) ranked the likely impact of different types of marine debris on marine mammals; From highest rank (risk) to lowest rank; Buoys/traps/pots; Monofilament; Fishing nets; plastic bags; Butts (cigarette butts); Plastic utensils; Balloons; Plastic caps; Food packaging; Plastic food lids; Straws/stirrers; Takeout containers; Hard plastic; Cans; Cups and plates; Glass bottles; Beverage bottles; Paper bags.

"Plastic" comprises synthetic or semi-synthetic organics polymers, polypropylene, nylon, polyesters, polyethylene terephthalate (PET), liquid crystal polymer (LCP), high-density polyethylene (HDPE), polyethylene Aramids and acrylics. Most rope and fishing gear, and much packaging, including packing straps, is now made from some form of braided or woven plastic, and this represent a potential to be a persistent type of marine debris. Because rope and net have been designed to withstand use in the sea, rope and net can have enormous breaking strength, and can be resistant to degradation by water, salt, and sunlight and abrasion. Many plastics are buoyant, or neutrally buoyant in seawater, and so either float at the surface, sink only very slowly in the sea, or are easily carried by currents. DuPont (E. I. du Pont de Nemours and Company, Delaware, USA) first sold nylon monofilament fishing line in 1938, and with each generation of development of these materials, the lines become stronger, less visible in water (low optical density), very strong, and very resistant to biting and chewing by trapped animals. 
Fishing lines are very strong in relation to their thickness, and their thin diameter can cut into, and damage tissues readily if an animal becomes entangled. It is estimated that some plastic filaments will last in the sea for up to 600 years (polymers of this type were only first used widely for rope and line since 1935, and so their long term lifespan in the environment can only be estimated). For these reasons, lost or abandoned fishing gear; nets, lines, monofilament fishing line, traps, and floats are a significant source of marine debris, and of particular concern for animal welfare, due to the capacity of these strong and persistent lines to entangle and trap animals in the sea. In a related way to "rope," the strong and persistent "packing bands" used to wrap containers and packages which are made from polypropylene, polyester or nylon, sometimes reinforced with fibers of other types of "plastic"-are very strong, resistant to degradation and can persist in the marine environment for decades. One particular concern with packing bands is that they are commonly found as "loops" (their functional purpose was to surround containers) and looped structures are much more likely to trap animals, including pinnipeds, than "open ended" lines or ropes.

In the United Kingdom, debris from fishing including nets, buoys, line and floats is the second most common type of marine debris after visitors' litter on beaches (Marine Conservation Society [MCS], 2007). The United States National Marine Debris Monitoring Program (Sheavly, 2007) indicated that $17.7 \%$ of beach litter came from fishing activity, fishing line, net, rope, floats and buoys, fish baskets, and pots and traps.

Marine debris results from a wide range of human activity; from intentional and unintentional losses from shipping, including fishing vessels; from deliberate or accidental dumping of domestic, commercial, or industrial waste into the sea, and derived from the land; or from windblown waste which comes from the shore, or waste from boats and land-based debris which is passed into the sea through wind, storm or river floods.

The origin (manufacturing origin, not disposal location) of plastic objects and packaging can be determined using barcodes (digits in the barcode indicate the country where the object was manufactured) and Santos et al. (2005) reported the source of strandline debris found Brazilian beaches, and found the country of origin of plastic debris to be; "USA $12.2 \%$, Italy $7.6 \%$, South Africa $6.4 \%$, Argentina 6.0\%, Germany 5.6\%, United Kingdom 4.6\%, Taiwan 4.4\%, Singapore 3.6\%, Spain 3.6\%, Malaysia $3.1 \%$, with others $35.2 \%$, and unidentified $7.6 \%$." Tracing of barcodes on plastic debris has shown that marine plastic debris can originate in one country and be found 10 years later $10,000 \mathrm{~km}$ away (Barnes et al., 2009). Zalasiewicz et al. (2016) note that degraded plastic is so widely spread now in ocean sediments that plastics will become one of the key geological indicator of the Anthropocene (current time, time of mankind), a distinctive stratal layer.

Some debris that originated on land, rather than from boat activity, has traveled in currents, into the ocean gyres, the giant rotating ocean currents. Debris in the oceans slowly breaks down into small particles (like sand) and plastic particles are found in the water and the ocean floor sediments across the world's oceans. The Great Pacific Oceanic Gyre contains plastic and debris with an estimated mass of 100 million tons, and concentrated into an accumulation estimated to be as large as Spain and France combined (Sheavly, 2007). Before the 1980s, only very small amounts of marine litter had reached the Southern Ocean islands. Plastic debris has now moved into the entire southern hemisphere, with increasing rates of accumulation on remote shores and with debris moving toward the Antarctic (Barnes, 2005). Plastics degradation can be slow in the marine environment, and Wang et al. (2016) discuss how, with the effects of UV-B radiation in sunlight and exposure to oxygen, autocatalytic degradation can occur, however, in the relatively low temperatures of the sea, the rate of degradation of many plastics in the marine environment is slow when compared to the terrestrial environment.

Educational programmes have been identified as one way to reduce marine wildlife entanglement. Pearson et al. (2014) describe a survey used to assess the familiarity of Australians in coastal communities with an initiative called "Seal the Loop" aimed at protecting seals from marine waste. Many participants were familiar with the education programme, however $32 \%$ of the participants were unable to explain what the risks to wildlife were, and they under-estimated the impact on wildlife numbers. This study identified that "learning something new, changed waste disposal behaviors."

\section{PLASTIC WASTE IMPACTS ON ANIMAL WELFARE THROUGH THE ENTANGLEMENT OF PINNIPEDS}

Many languages have a term for "welfare" as used in the context of animal welfare or wellbeing. For example: in German, wohlbefinden-well-being, wellness, physical comfort: in French, bien-être-well-being, a sense of wellbeing: in Spanish, benestarstate of health, prosperity.

In many considerations of animal welfare, the description of "good welfare" includes the animal being "well" and also having the potential for "wellbeing" - being at ease or, at least, not subject to distress. Many people consider disease or physiological or anatomical damage, injury, or trauma as providing challenges which mean that an animal is unlikely to experience high levels of animal welfare. Sandoe and Simonsen (1992) uses the term "cost of coping": that emotional distress, pain, or increased levels of physiological or disease related challenge have a cost, and if that cost is great, then the animal is less likely to cope, and that prolonged failure to cope will result in suffering. For wild animals, entanglement can result in altered feeding behaviors and altered food sources, altered social interactions and breeding patterns, altered migration, hunting or foraging patterns, altered breeding, and altered territorial or animal human interactions. For the individual entangled animal, the capacity to cope (or not) will depend on the severity of the restriction, whether the entanglement interferes with movement, and, in severe cases, whether the entanglement causes incisive wounds, trauma, skin lesions, or inability to swim, mate, or feed. Will the entanglement result in disease through skin or muscle lesions, or results in starvation inability to forage, hunt, and feed? The types of marine debris found in the environment of different pinnipeds are likely 
to profoundly influence whether entanglement happens, what the entanglement is with, how often and how severely the animal is affected, and the outcome. Entanglement may cause immediate and severe welfare problems such as asphyxiation, or trapping underwater, or may be "chronic" with prolonged periods of entanglement in rope or net, and where the welfare impacts may increase over time as infection, progressive tissue damage and weight loss start to act.

A large number of pinniped species have been recorded entangled, and a review of the literature shows the global nature of this problem. Entanglement has been noted in 58 per cent of all species of seals and sea lions (Boland and Donohue, 2003). The incidence rate of entanglement for seal and sea lion species is estimated to be in the range at $0.001-5 \%$ of the population annually, with a high incidence of up to $7.9 \%$ in Mexican California sea-lions (Harcourt et al., 1994). Williams et al. (2011), describe the entangled seal species found around the coast of British Columbia in Steller sea lion (Eumetopias jubatus), harbor seal (Phoca vitulina) and in northern elephant seals (Mirounga angustirostris), and a study by Derraik (2002), on Bering Sea northern fur seals, estimated that 40,000 seals a year were entanglement in and killed by plastic waste.

When seals become entangled, the "trapping" may involve a ring of packing strap, fishing net, monofilament line or net, which commonly forms a collar around the neck. The loop tightens as the animal grows or, may be trapped by the nature of the coat (which is flattened against the body in the direction of least water resistance), and in adult seals, the loop can incise the tissues of the neck or flipper and become firmly embedded in the skin, subcutaneous fat or the muscle, and even into bone. It is believed that, for many cases, the loop becomes deeply enmeshed or embedded in tissue and it becomes unlikely that the animal can remove it (Lawson et al., 2015). The majority of entanglements appear to be in young seals, which, it may be surmised, is because they are curious, exploratory, or naïve or inexperienced feeders, unfamiliar with the hazards of rope or fishing net fragments. Young seals find themselves wrapped up in rope, net or monofilament loops, and these become firmly fixed around the neck or the body close to the flipper, and this constriction may restrict feeding to the point of starvation. These rope and monofilament line ligatures can cause acute cutting damage and amputation of flippers, and can leave wounds which, because they contain a foreign body (rope or line), remain open to long term infection, reducing the likelihood of survival. The constriction may sever arteries, and finally cause death by strangulation. Because plastic is extremely durable in the marine environment, it is possible that, when the entangled animal dies, the debris or entangling rope or net may returned to the sea with the potential to entangle other animals (WSPA, 2012). Entangled pinnipeds will sometime require to increase their metabolism to compensate for the increased drag caused by the entangling objects during swimming (Boland and Donohue, 2003), and Derraik (2002) describe how Northern Fur Seals (Callorhinus ursinus) carrying net fragments of as little as 200 grams in weight had up to a four-fold increase in the quantity of food that was required to be consumed to compensate for drag caused by interference with water flow. This drag effect may produce large energetic burdens, and restrict movement and ultimately lead to exhaustion and drowning. Where pinnipeds including stellar sea lions (E. jubatus) in Alaska and British Columbia ingest fishing gear equipped with hooks, or lines with lures or fish flashers, these hooks and lines can lodge inside the animal and can damage the mouth and the lower digestive system, or reduce the animal's capacity to forage and feed effectively.

\section{Severity Scoring for Pinniped Interactions with Marine Debris}

In human medicine, well established scoring scales for wounds are used to enable clinicians to communicate the severity of wounds and to guage how they are healing, and internationally, the Red Cross classification of war wounds is used to describe wounds based on their visual appearance (and is not based on what caused them; Coupland, 1992). In a related way, work has been initiated on assessment of the severity of entanglements in marine mammals, and the NOAA/NMFS Injury Technical Workshop, held in Seattle in 2007 (NOAA/NMFS, 2007), proposed a hierarchical descriptive scale for injuries to marine mammals. The following area of entanglement and injury related to human activity were categorized:

\begin{abstract}
"Serious-gear-related injury; Ingestion of gear; Trailing gear (e.g., flasher or lure), when it has the potential to anchor or drag, or when it is wrapped around the animal; Gear attached to the body with the potential to wrap around flippers, body, or head; Foreign bodies penetrating into a body cavity; Multiple wraps around the body; Missing flippers-front and back flipper (serious), for both otariids or phocids; Deep external injuries.
\end{abstract}

\begin{abstract}
Non-serious-gear-related injuries; Hooked in the lip; Hooked in flipper, etc. with minimal trailing gear that does not have the potential to wrap around body parts, accumulate drag, or anchor; Freely swimming animals encircled by purse seine nets.
\end{abstract}

Gray area-gear-related injuries (less clear how serious the welfare impact is): Hooked in head (serious injury could be assumed, but it depends on several factors, including where on the head the hooking took place, the depth of the hooking, the type of hook, etc.); animals stressed by being encircled or trapped (e.g., purse seine); Animals released without gear following entanglement (this designation depends on the extent of the injury or how long the animal was submerged, how long the gear was on the animal, and the degree of restraint).

Other impacts of interactions with humans: Pinniped brought onto a vessel (this was considered in the report to be non serious, and the severity dependent on how the animal was brought up (e.g., in net or a roller, or through the power block)."

Some examples of "serious scores" to illustrate the range of possible welfare insults causing severe welfare insults based on descriptions of observed seal entanglements from Spraker and Lander (2010); Severe impacts.

\footnotetext{
"Rope fragment wrapped around shoulder, strands had cut through muscles of right shoulder and halfway through the mid-portion of the humerus"
} 


\begin{abstract}
"Material wrapped around upper neck, line had cut through lower half of trachea."

"Line Wrapped around mid-neck, had cut through all dorsal muscles of neck exposing dorsal spinal processes of cervical vertebrae."
\end{abstract}

In the following sections, a review of studies describing the impacts of entanglement on specific pinniped species is presented;

\section{Fur Seals}

Hofmeyr et al. (2002) report 101 fur seals (Arctocephalus spp.) and five southern elephant seals (Mirounga leonina) which were entangled in debris at Marion Island in the Southern Ocean over a 10-year period. These authors describe how $67 \%$ of the entangling materials derived from the fishing industry. Polypropylene packaging straps and trawl netting were the most commonly found entangling debris. They also reported longline hooks seen embedded in animals, and also report that fishing line entanglements only started to be encountered in the waters around Marion Island after the start of longline fishing in 1996. These authors estimated that $0.24 \%$ of the population of fur seals were entangled annually. Hofmeyr et al. (2006) also made observations of Antarctic fur seals (Arctocephalus gazella) from 1996 to 2002 on the sub-antarctic island, Bouvetøya. They report entanglement rates of between 0.024 and $0.059 \%$, and they conclude that these rates are comparatively low when compared to other pinniped populations, and surmise that this is because of the geographic isolation of the site. This study found that over two-thirds of entangling materials were derived from fisheries sources.

Spraker and Lander (2010) describe the causes of mortality in Northern Fur Seals (C. ursinus) on St. Paul Island, Alaska, and describe some of the horrible combinations of entanglement, asphyxiation and tissue trauma caused by net and packing band loops. In one case described, a living but heavily entangled animal is dragging a dead and decomposing seal in the same piece of net.

Lawson et al. (2015) describe sampling work carried out at Seal Rocks, Lady Julia Percy Island, Kanowna Island, Berry's Beach, Cowes jetty and Western Port in Southern Australia. These islands had at the time of the study an estimated Australian fur seal (Arctocephalus pusillus doriferus) populations of around 30,000 individuals. Over a period from 1997 to 2012, 138 entanglement items were collected and stored by the project. Fifty percent $(n=69)$ of the objects were made of plastic twine or rope (including trawl nets), 20\% $(n=27)$ were made of other plastics such as plastic bags, packing straps, and balloon ribbon, $17 \%(n=24)$ were monofilament line, including gill nets and $8 \%(n=11)$ were comprised of rubber. The remaining $5 \%(n=7)$ consisted of metal items (such as hooks and lures) and cotton (a baseball cap that resulted in a neck constriction). White plastic packaging strapping formed the majority $(67 \%$, $n=6)$ of the strap entanglements. These authors found that $61 \%(n=43)$ of twine/rope entanglements involved green material, whereas gray and white colored rope items accounted for only $10 \%(n=7)$ and $9 \%(n=6)$ respectively, and that for monofilament line, more monofilament was clear or green in color (52 and 26\%, respectively). The characteristics of the entangling material was also noted; type, color, overall size, mesh size, diameter, number of threads, whether the item was braided, twisted, knotted, if it was monofilament and number of strands for all entanglement items. Where available, information on the date and location, the age class of the seal (pup, juvenile, adult), and the severity of the injury (whether cutting deep or surface wound) was also collated. This data set showed that the overwhelming majority $94 \%(n=46)$ of entanglements involved young juvenile or pup seals, with more pups (53\%) than juveniles (41\%) being entangled. McIntosh and others (McIntosh et al., 2015) working at Seal Rocks, South-Eastern Australia reported 359 entangled Australian fur seals, and showed that the most common entanglement materials were from commercial fisheries and that entanglements were most frequent in pups and juveniles. This study indicated that entanglement was more commonly observed from July to October, when the young animals approached weaning, and using a Generalized Additive Mixed Models (GAMMs) these authors estimated that $1.0 \%$ $(\mathrm{CI}=0.6-1.7 \%)$ of the local population was entangled each year.

The loop diameters of entangling materials which entangled Antarctic fur seals from a study at Bird Island, South Georgia are described by Waluda and Staniland (2013). They reported material found entangling 90 animals, with loops from 11 to $69 \mathrm{~cm}$ in diameter (with a median diameter of $18 \mathrm{~cm}$ ). These authors found that loop diameter was closely related to age class: very young animals commonly entangled in smaller loops $($ median $=15.5 \mathrm{~cm})$ : juveniles $(18 \mathrm{~cm})$ and adult females $(17$ $\mathrm{cm}$ ) entangled in similar loop diameters. Adult males were more likely to be found with larger loops of median diameter 34 $\mathrm{cm}$. These authors reported that juveniles were five times more likely to be entangled than adult females. They proposed that younger animals were more likely to entangle whilst interacting with debris through curiosity and play. Adult males were the least likely of the age classes to be entangled. This was proposed to be potentially a result of their broad muscular necks, their relatively lower numbers within the overall population, and also potentially due to behavioral differences. This report also noted that that if the entanglement was fatal prior to adulthood, then individuals prone to entanglement could have been selected from the population. This study also reported that there were more "very severe" entanglements during the winter than the summer. The authors speculate that this may be a reflection of changes in the ability to observe animals rather than a true alteration in entanglement rate, as the animals which are hauled out (on the shoreline) would been removed from ready observation (i.e., hauled out away from human occupation, or at sea) during the winter months. This report also identified a potential decline in the number of seals entangled in packaging bands at Bird Island over time. In 1988/99-58\% of entanglements were with packing bands, between 1989 and 1994 this fell to $46 \%$, and between 1994 and 2013 the proportion was 39\%. These authors propose that the Commission for the Conservation of Antarctic Marine Living Resources (CCAMLR) legislation to 
ban packaging bands, which was initiated in 1995 may have had a reducing (but not eliminating) effect on packing band entanglements. In the Antarctic, entanglement of Antarctic fur seals (A. gazella) reduced by 50\% over the 5 years (1990-1994) after the introduction of MARPOL Annex V (MARPOL is the International Convention for the Prevention of Pollution from Ships ${ }^{1}$ however, fishing net, polypropylene packing bands, and synthetic string and rope were still found as common debris items entangling seals across all years (Arnould and Croxall, 1995).

In New Zealand, Page et al. (2004) indicate that fur seals were found to be entangled in packing tape loops, and trawl net fragments, which were believed to have been derived from local rock lobster and trawl fisheries. These authors (Page et al., 2004) also reported entanglement for New Zealand fur seals and Australian sea lions: the Australian sea lion entanglement rate was estimated at $1.3 \%$ of the population annually, and the New Zealand Fur seal entanglement rate as $0.9 \%$. Australian sea lions were most frequently entangled in monofilament line or net, which may have derived from the local shark fishery.

On St Paul Island, in the Alaskan Pribilof Islands, Northern fur seals (C. ursinus) were reported by Fowler (1987) with various objects around their necks, shoulders and flippers, with an estimated incidence rate amongst sub-adult males of about $0.4 \%$. The majority of entanglements were trawler fishing net fragments and plastic packing bands. These authors noted that entanglement was more commonly seen in young animals, which were "sometimes observed entangled together in groups attached to the same large items of debris." Shaughnessy (1980) describes Cape fur seals (Arctocephalus pusillus), entangled between 1972 and 1979, with the majority of the entangling objects, being on the seals' necks. The highest incidence was recorded at the Cape Cross colony, at $0.56-0.66 \%$, animals being entangled with string, rope, fishing net, plastic straps, monofilament line, rubber O-rings, and wire. Boren et al. (2006) reported that several thousand Antarctic fur seals from South Georgia were caught in lost fishing gear, with an estimated rate of entanglement of $0.4 \%$ of the population, and these authors estimated that 15,000 seal entanglements took place each year, of which they estimated 5700 would be likely to die as a result. Allen and Angliss (2014) describes entanglement of Northern fur seals at St. George Island, with mean entanglement rates of $0.06-0.08 \%$ for very young animals, and a seasonal variability and the a maximum rate occurring in October of up to $0.11 \%$ just before weaning. The rate of juvenile male entanglement reported in these studies was particularly high in 2005-2006, with between 0.15 and $0.35 \%$ of the population becoming entangled, based on observational studies.

New Zealand fur seals (Arctocephalus forsteri) from Kaikoura have a breeding area close to a busy tourist and fishing area, and are reported to become entangled in nets and plastic waste (Boren et al., 2006). Entanglement rates are described from

${ }^{1}$ MARPOL International Convention for the Prevention of Pollution from Ships (MARPOL) International Maritime Organization Retrieved 27/6/16; http:// www.imo.org/en/About/Conventions/ListOfConventions/Pages/InternationalConvention-for-the-Prevention-of-Pollution-from-Ships-(MARPOL).aspx
0.6 to $2.8 \%$ of the local population annually, with green trawl net fragments (42\%), and plastic strapping (31\%) noted as the most common entangling materials. Perhaps because of the high density of "observers" in this area, nearly half (43\%) of the entangled seals described in this study were successfully treated and released. Post-release surveys showed that the probability of an entangled individual surviving after release was high, even after having suffered a significant wound from the entanglement.

Hanni and Pyle (2000) in studies from South East Farallon Island, in North California, between 1976 and 1998,describe 914 Northern Elephant Seals (M. angustirostris), Steller Sea Lions (E. jubatus), California Sea Lions (Zalophus californianus), Northern Fur Seals (C. ursinus), and Pacific Harbor Seals ( $P$. vitulina), reported entangled. The materials that these authors report causing entanglement were "monofilament line and net, heavy fishnet material, other net material, salmon fishing lure and line, fish hooks and line, packing straps, other miscellaneous marine debris, and 'constriction' (where no actual material was observed, presumed to be hidden in the fur or wound, but a circular indentation was present around the head, neck or torso)."

\section{Sea Lions}

In Australia, an estimated 1500 Australian sea lions (Neophoca cinerea) are estimated to die through entanglement, mostly from trapping in monofilament gillnet associated with the shark fishery local to the sea lion foraging area (Page et al., 2003).

In California, Dau et al. (2009) reported 1090 pinniped entanglements, of which $11.3 \%$ were linked to fishing gear, and with a high prevalence of fishing gear injury reported from the San Diego region. Zavala-González and Mellink (1997) describe entanglement rated for California sea lion (Z. californianus) from a population which extends from British Columbia to Mazatlan in Mexico, including populations in the Gulf of California. The population of sea lions in the Mexican part of this range is estimated at $\sim 74,500$ individuals on the Pacific coast, and 28,220 animals from the Gulf of California, and the annual entanglement rate for these animals is estimated to be $2.24 \%$.

A survey of 386 Steller sea lions (E. jubatus) reported an estimated incidence rate for entanglement of $0.26 \%$ of the population in northern British Columbia and Southeast Alaska (Raum-Suryan et al., 2009). These authors examined materials causing entanglement and found that: "packing bands (54\%) were most common, followed by large rubber bands (rubber packing bands; 30\%), net (7\%), rope (7\%) and monofilament line (2\%)." This study also describes the types of fishing gear ingested or entangling these animals, and this included: "salmon fishery flashers/lures (80\%), long-line gear (12\%), hooks and line (4\%), spinners or spoons (2\%), and bait hooks (2\%)." Raum-Suryan et al. also describe the local campaign called "Lose the Loop!" which promoted procedures such as cutting entangling loops of synthetic material and eliminating packing bands to help prevent entanglements. Work reported by the National Oceanic and Atmospheric Administration (NOAA, 2012) report that packing bands cause greater than $50 \%$ of neck entanglements seen in Steller sea lions (E. jubatus) in Alaska. 


\section{Elephant Seals}

The impact of entanglement on Southern Elephant Seals ( $M$. leonina) is discussed by Campagna et al. (2007), and the characteristic wound around the neck caused by monofilament lines is described. In this study, entangled Elephant Seals were caught, and in the majority of cases the material which was removed was monofilament line typically $1.3-1.5 \mathrm{~mm}$ thick and tied in a circle with a knot. In some animals, this monofilament line had colored lures armed with hooks attached, a configuration typical of squid fishing gear. These authors estimate that the rate of entanglement was relatively low, $0.001 \%$, however, they suggest this to be an underestimate since the observations they made were taken at a time when juveniles-in many seal species, the most commonly affected group-were not present in the population. These authors describe how the monofilament entanglement becomes a chronic wound, with infection and with debilitating consequences, and they describe how, based on assessment of the depth of the wounds, some entangled seals may have survived for months or years with monofilament line incising the skin and muscle tissues around the neck.

\section{Monk Seals}

Donohue and Foley (2007) assessed the effects of weather and storms on monk seal entanglement rates in the North Pacific Ocean, and reported that in the 23 years leading up to the year 2007, monk seal entanglement increased during the times when the El Niño weather system was operating. They proposed that the oceanographic processes linked with El Niño contributed to changes in entanglement rates, perhaps as a result of introduction of new debris material along with the changes in ocean currents. The Hawaiian monk seal (Monachus schauinslandi) is an endangered species, limited to breeding on six small islands and atolls in North-West Hawaii. Between 1996 and 2000 a multi-agency initiative took place to reduce the amount of lost fishing gear and fishery derived material found in the reefs of these Hawaiian Islands. These reefs are close to the breeding sites for these seals, and were systematically cleaned up (Boland and Donohue, 2003) and 195 tons of abandoned, lost or otherwise discarded fishing gear (ALDFG) were removed from the area.

Karamanlidis (2000) found that ALDFG had a measurable effect on the monk seal (Monachus monachus) population in the Mediterranean, and this author argued that the use of gillnets threatened the small and endangered monk-seal colony which is found around the Desertas Islands, Madeira.

\section{Gray Seals and Common Seals}

The type and rate of entanglement seen in gray seals (Halichoerus grypus) stranded on the Dutch coast, between 1985 and 2010, are described by Hekman and Osinga (2010). This study reports that entanglement was more common in gray seals than common seals ( $P$. vitulina; about twice as common) and that for both species a larger proportion of the entangled seals were males and that entanglement was most frequent in juveniles. Discarded trawl nets and gillnets were the most common entangling material, and these authors indicate that the numbers seen and reported were probably only a small part of the true extent of animal lost to entanglement because it was assumed that most animals would be undetected and lost at sea.

Allen et al. (2012) discuss the physiological and anatomical effects of entanglement on gray seals (H. grypus) and describe how an important (and under reported) aspect of entanglement are the effects of increased drag through the resistance trailing material, and the increase in time spent foraging due to increased metabolic demands from drag. These authors also comment on the animal welfare impact of the injuries sustained, and the types of injuries sustained by the animals to be "constriction" (43\%); "wound" (7\%); "constriction and wound" (14\%); "evident" (visible entanglement but wound type unclear; 36\%). Allen et al. (2012) also describe how entangled seals form " $8.7 \%$ of the seals on the Cornish photo ID database (as of the end of 2011), and that of 58 seals on the database, 37 (64\%) had injuries that were causing a constriction or had formed an open wound, or both." They estimate entanglement rates in these seals from $5 \%$ of the population in 2004 to $3.1 \%$ in 2011.

\section{CONCLUSIONS}

Pinnipeds are at the visible end of the spectrum of animals which become entangled, snared, trapped or caught in marine debris, particularly plastics in the form of net, rope, monofilament line and packing bands, with severe consequences, and the potential for acute welfare impacts on the individual animals. Plastic in the ocean is a "new" challenge to these animals, man-made and found only in any quantity in this century, and with an apparent dramatic rise in quantity, spread and effect in the last 20 years. Plastic is likely to be very long lived in a marine environment (we don't yet know how long in practice), as there are still plastic objects floating in the sea that were manufactured in the 1950s. The effects of marine debris, particularly of plastics, are not only aesthetic, they have the potential to cause significant, widespread and "mostly hidden and unreported" animal suffering, though constriction, wounding, drag, amputation, compromised feeding, and gut impaction or trauma if ingested. Studies reviewed here describe how entanglement lesions become chronic wounds, with infection and with debilitating consequences, and they describe how entangled pinnipeds may live for months or years with plastic line, or net, cutting into skin and muscle tissues.

The pinniped species most affected (Table 1; all species however can potentially be affected) through entanglement are: monk seals, fur seals and California sea lions, and to a lesser extent gray, common and monk seals. Entanglement rates described in the literature range up to $7.9 \%$ of local populations annually, and the literature refers repeatedly to the common entangling materials; packing bands, fragments of lost net, rope, monofilament line, fishery flashers and lures, long-line fishing gear, hooks and line, and bait hooks. 
TABLE 1 | Summary tabulation of reported entanglement rates for the pinniped species found in different ocean regions-the rate of entanglement (estimated \% of population annually), and the net, plastic, and fishing line (\% of reported entanglement cases for each category respectively), and the published source of the data.

\begin{tabular}{|c|c|c|c|c|c|c|}
\hline Ocean region & Species/sub species & Rate of entanglement (\%) & Net & Plastic & Fishing line & Published source \\
\hline \multirow[t]{3}{*}{ North East Pacific } & Steller seal lion & 0.26 & 7 & 54 & 2 & Raum-Suryan et al., 2009 \\
\hline & Northern fur seal & 0.4 & 65 & 19 & & Fowler, 1987 \\
\hline & Northern fur seal & $0.08-0.35$ & 39 & 37 & 9 & Allen and Angliss, 2014 \\
\hline \multirow[t]{6}{*}{ Eastern Central Pacific } & Californian sea lion & $0.08-0.22$ & 19 & 25 & 14 & Stewart and Yochem, 1987 \\
\hline & Californian sea lion & $3.9-7.9$ & 50 & & 33 & Harcourt et al., 1994 \\
\hline & Northern elephant & 0.15 & 19 & 36 & 33 & Stewart and Yochem, 1987 \\
\hline & Harbor seal & 0.09 & & 33 & & Stewart and Yochem, 1987 \\
\hline & Northern fur seal & 0.24 & 50 & & & Stewart and Yochem, 1987 \\
\hline & Steller seal lion & & 4 & & 4 & Hanni and Pyle, 2000 \\
\hline Central Pacific & Hawaiian monk seal & 0.7 & 32 & 8 & 28 & Henderson, 2001 \\
\hline South West Pacific & Kaikoura fur seal South & $0.6-2.8$ & 42 & 31 & & Boren et al., 2006 \\
\hline North West Atlantic & Gray seal & $3.1-5$ & & & & Allen et al., 2012 \\
\hline \multirow[t]{3}{*}{ South East Atlantic } & Antarctic fur seal & $0.024-0.059$ & 48 & 18 & & Hofmeyr et al., 2002 \\
\hline & Antarctic fur seal & 0.4 & & $46-52$ & & Arnould and Croxall, 1995 \\
\hline & Cape fur seal & $0.1-0.6$ & & 50 & & Shaughnessy, 1980 \\
\hline \multirow[t]{4}{*}{ South West Atlantic } & Southern elephant seal & $0.001-0.002$ & & 36 & 64 & Campagna et al., 2007 \\
\hline & Australian fur seal & 1.9 & 40 & 30 & & Pemberton et al., 1992 \\
\hline & New Zealand fur seal & 0.9 & 29 & 30 & 3 & Page et al., 2004 \\
\hline & Australian sea lion & 1.3 & 66 & 11 & 6 & Page et al., 2004 \\
\hline Western Indian Ocean & Antarctic and Sub Antarctic fur seal & 0.24 & 17 & 41 & 10 & Hofmeyr et al., 2002 \\
\hline
\end{tabular}

Highlighted line (gray), indicates estimated annual entanglement rates of $>1 \%$.

Awareness of the issue by the public, governments and industry is increasing, and local action is reported by some authors to have made measurable differences in entanglement rates. The spread of plastic material in the ocean will leave many seals unseen in their contortions to remove entangling material, and this is a hidden horror taking place in the ocean resulting from human activity which was not anticipated, but is having a significant effect on animal welfare and will be notable in future analysis of human effects on wild animals as a recognizable stage in the evolution of the interaction of wild animals and mankind.

\section{REFERENCES}

Allen, B. M., and Angliss R. P. (2014). National Fur Seal (Callorhinus ursinus): Eastern Pacific Stock; Annual Human - Caused Mortality and Serious Injury National Oceanic and Atmospheric Administration. Available online at: http://www.nmfs.noaa.gov/pr/sars/pdf/stocks/alaska/2014/ak2014_ northernfurseal-cp.pdf

Allen, R., Jarvis, D., Sayer, S., and Mills, C. (2012). Entanglement of grey seals Halichoerus grypus at a haul out site in Cornwall, UK. Mar. Pollut. Bull. 64, 2815-2819. doi: 10.1016/j.marpolbul.2012.09.005

Arnould, J. P. Y., and Croxall, J. P. (1995). Trends in entanglement of Antarctic fur seals (Arctocephalus gazella) in man-made debris at South Georgia. Mar. Pollut. Bull. 30, 707-712.

\section{AUTHOR CONTRIBUTIONS}

The author confirms being the sole contributor of this work and approved it for publication.

\section{FUNDING}

This review was carried out as a result of the individual academic interests of the author and was not funded by a specific funding body.
Barnes, D. K. A. (2005). Remote islands reveal rapid rise of Southern Hemisphere sea debris. Scientific WorldJournal 5, 915-921. doi: 10.1100/tsw.2005.120

Barnes, D. K. A., Galgani, F., Thompson, R. C., and Barlaz, M. (2009). Accumulation and fragmentation of plastic debris in global environments. Philos. Trans. R. Soc. B 364, 1985-1998. doi: 10.1098/rstb.2008.0205

Boland, R. C., and Donohue, M. J. (2003). Marine debris accumulation in the nearshore marine habitat of the en- dangered Hawaiian monk seal, Monachus schauinslandi 1999-2001. Mar. Pollut. Bull. 46, 1385-1394. doi: 10.1016/S0025326X(03)00291-1

Boren, L. J., Morrissey, M., Muller, C. G., and Gemmell, N. J. (2006). Entanglement of New Zealand fur seals in man-made debris at Kaikoura, New Zealand. Mar. Pollut. Bull. 52, 442-446. doi: 10.1016/j.marpolbul.2005. 12.003 
Campagna, C., Falabella, V., and Lewis, M. (2007). Entanglement of southern elephant seals in squid fishing gear. Mar. Mamm. Sci. 23, 414-418. doi: 10.1111/j.1748-7692.2007.00105.x

Cole, T., Hartley, D., and Garron, M. (2006). "Mortality and serious injury determinations for baleen whale stocks along the Eastern Seaboard of the United States, 2000-2004," in Northeast Fisheries Science Center Reference Document, 06-04 (Woods Hole, MA: National Marine Fisheries Service), 18.

Convention on Biological Diversity (CBD) (2012). Secretariat of the Convention on Biological Diversity and the Scientific and Technical Advisory Panel-GEF (2012). Impacts of Marine Debris on Biodiversity: Current Status and Potential Solutions, Montreal, Technical Series No. 67. Available online at: https://www. cbd.int/doc/publications/cbd-ts-67-en.pdf

Coupland, R. M. (1992). The Red Cross classification of war wounds: the E.X.C.F.V.M. scoring system. World J. Surg. 16, 910-917. doi: 10.1007/BF02066991

Dau, B. K., Gilardi, K. V., Gulland, F. M., Higgins, A., Holcomb, J. B., Leger, J. S., et al. (2009). Fishing gear-related injury in California marine wildlife. J. Wildl. Dis. 45, 355-362. doi: 10.7589/0090-3558-45.2.355

Derraik, J. G. B. (2002). The pollution of the marine environment by plastic debris: a review. Mar. Pollut. Bull. 44, 842-852. doi: 10.1016/S0025-326X(02)0 0220-5

Donohue, M. J., and Foley, D. G. (2007). Remote sensing reveals links among the endangered Hawaiian monk seal, marine debris, and El Niño. Mar. Mamm. Sci. 23, 468-473. doi: 10.1111/j.1748-7692.2007.00114.x

Fowler, C. W. (1987). Marine debris and northern fur seals: a case study. Mar. Pollut. Bull. 18, 326-335. doi: 10.1016/S0025-326X(87)80020-6

Hanni, K. D., and Pyle, P. (2000). Entanglement of Pinnipeds in Synthetic Materials at South-east Farallon Island, California, 1976-1998. Mar. Pollut. Bull. 40, 1076-1081. doi: 10.1016/S0025-326X(00)00050-3

Harcourt, R., Aurioles, D., and Sanchez, J. (1994). Entanglement of California sea lions at Los Islotes, Baja California Sur, Mexico. Mar. Mamm. Sci. 10, 122-125. doi: 10.1111/j.1748-7692.1994.tb00399.x

Hekman, R., and Osinga, N. (2010). Stichting Zeehondencreche Lenie t' Hart 2010. Available online at: http://www.zeehondencreche.nl/wb/pages/ wetensch.-onderzoek/wetenschappelijke-publicaties.php (Accessed April 2, 2016).

Henderson, J. R. (2001). A pre- and post-MARPOL Annex V summary of Hawaiian monk seal entanglements and marine debris accumulation in the northwestern Hawaiian Islands, 1982-1998. Mar. Pollut. Bull. 42, 584-589. doi: 10.1016/S0025-326X(00)00204-6

Hofmeyr, G. J., Bester, M., Kirkman, S. P., Lydersen, C., and Kovacs, K. M. (2006). Entanglement of Antarctic fur seals at Bouvetøya, Southern Ocean. Mar. Pollut. Bull. 52, 1077-1080. doi: 10.1016/j.marpolbul.2006.05.003

Hofmeyr, G. J. G., De Maine, M., Bester, M. N., Kirkman, S. P., Pistorius, P. A., and Makhado, A. B. (2002). Entanglement of pinnipeds at Marion Island, Southern Ocean: 1991-2001. Aust. Mammal. 24, 141-146. doi: 10.1071/A M02141

International Coastal Cleanup (ICC) (2008). Annual Report-Ocean Conservancy 2008. Available online at: http://www.oceanconservancy.org/our-work/ marine-debris/2016-data-release/2016-data-release-1.pdf (Accessed June 27, 2016).

Karamanlidis, A. A. (2000). Monitoring Human and Mediterranean Monk Seal Activity in the National Marine Park of Alonnissos and Northern Sporades, Greece. Monachus Guardian. Available online at: http://www.monachusguardian.org

Lawson, T. J., Wilcox, C., Johns, K., Dann, P., and Hardesty, B. D. (2015). Characteristics of marine debris that entangle Australian fur seals (Arctocephalus pusillus doriferus) in southern Australia. Mar. Pollut. Bull. 98, 354-357. doi: 10.1016/j.marpolbul.2015.05.053

Marine Conservation Society (MCS) (2007). Beachwatch 2006. The 14th Annual Beach Litter Survey Report. Marine Conservation Society, Ross on Wye. Available online at: https://www.mcsuk.org/press/view/181 (Accessed April 6, 2016).

McIntosh, R. R., Kirkwood, R., Sutherland, D. R., and Dann, P. (2015). Drivers and annual estimates of marine wildlife entanglement rates: a long-term case study with Australian fur seals. Mar. Pollut. Bull. 101, 716-725. doi: 10.1016/j.marpolbul.2015.10.007

Moore, M. J., van der Hoop, J., and Barco, S. G. (2013). Criteria and case definitions for serious injury and death of pinnipeds and cetaceans caused by anthropogenic trauma. Dis. Aquat. Organ. 103, 229-232. doi: 10.3354/dao02566

NOAA (2012). Marine Mammal Entanglement: Pinniped. Available online at: https://alaskafisheries.noaa.gov/pr/pinniped-entanglement (Accessed July 12, 2016).

NOAA/NMFS (2007). Serious Injury Technical Workshop, Seattle, 2007 Severity Indexes Page 7. Available online at: http://www.nmfs.noaa.gov/ pr/pdfs/interactions/serious_injury_techmemo2008.pdf (Accessed April 2, 2016).

NRC National Research Council (2008). Tackling Marine Debris in the 21st Century. Committee on the Effectiveness of International and National Measures to Prevent and Reduce Marine Debris and its Impacts. Available online at: http://docs.lib.noaa.gov/noaa_documents/NOAA_related_docs/marine_ debris_2008.pdf (Accessed April 2, 2016).

Page, B., McKenzie, J., McIntosh, R., Baylis, A., Morrissey, A., Calvert, N., et al. (2004). Entanglement of Australian sea lions and New Zealand fur seals in lost fishing gear and other marine debris before and after Government and industry attempts to reduce the problem. Mar. Pollut. Bull. 49, 33-42. doi: 10.1016/j.marpolbul.2004.01.006

Page, B., Welling, A., Chambellant, M., Goldsworthy, S. D., Dorr, T., and van Veen, R. (2003). Population status and breeding season chronology of Heard Island fur seals. Polar Biol. 26, 219-224. doi: 10.1007/s00300-003-0478-Z

Pearson, E., Mellish, S., Sanders, B., and Litchfield, C. (2014). Marine wildlife entanglement: assessing knowledge, attitudes, and relevant behaviour in the Australian community. Mar. Pollut. Bull. 89, 136-148. doi: 10.1016/j.marpolbul.2014.10.014

Pemberton, D., Brothers, N. P., and Kirkwood, R. (1992). Entanglement of Australian fur seals in man-made debris in Tasmanian waters. Wildlife Res. 19, 151-159. doi: 10.1071/WR9920151

Raum-Suryan, K. L., Jemison, L. A., and Pitcher, K. W. (2009). Entanglement of steller sea lions (Eumetopias jubatus) in marine debris: identifying causes and finding solutions. Mar. Pollut. Bull. 58, 1487-1495. doi: 10.1016/j.marpolbul.2009.06.004

Sandoe, P., and Simonsen, H. B. (1992). Assessing animal welfare: where does science end and philosophy begin? Anim. Welfare 1, 257-267.

Santos, I. R., Friedrich, A. C., and Barretto, F. P. (2005). Overseas garbage pollution on beaches of northeast Brazil. Mar. Pollut. Bull. 50, 782-786. doi: 10.1016/j.marpolbul.2005.04.044

Shaughnessy, P. D. (1980). Entanglement of Cape fur seals with manmade objects. Mar. Pollut. Bull. 11, 332-336. doi: 10.1016/0025-326X(80)9 0052-1

Sheavly, S. B. (2007). National Marine Debris Monitoring Program. Final Program Report, Data Analysis and Summary. Prepared for U.S. Environmental Protection Agency by Ocean Conservancy, Grant Number X830534 01-02, 76 .

Spraker, T. R., and Lander, M. E. (2010). Causes of Mortality in Northern Fur Seals (Callorhinus ursinus), St. Paul Island, Pribilof Islands, Alaska, 1986-2006. J. Wildl. Dis. 46, 450-473. doi: 10.7589/0090-3558-46.2.450

Stewart, B. S., and Yochem, P. K. (1987). Entanglement of pinnipeds in synthetic debris and fishing net and line fragments at San Nicolas and San Miguel Islands, California, 1978-1986. Mar. Pollut. Bull. 18, 336-339. doi: 10.1016/S0025$326 \mathrm{X}(87) 80021-8$

Waluda, C. M., and Staniland, I. J. (2013). Entanglement of Antarctic fur seals at Bird Island, South Georgia. Mar. Pollut. Bull. 74, 244-252. doi: 10.1016/j.marpolbul.2013.06.050

Wang, J., Tan, Z., Peng, J., Qiu, Q., and Li, M. (2016). The behaviors of microplastics in the marine environment. Mar. Environ. Res. 113, 7-17. doi: 10.1016/j.marenvres.2015.10.014

Wilcox, C., Mallos, N. J., Leonard, G. H., Rodriguez, A., and Hardesty, B. D. (2016). Using expert elicitation to estimate the impacts of plastic pollution on marine wildlife. Mar. Policy 65, 107-114. doi: 10.1016/j.marpol.2015. 10.014

Williams, R., Ashe, E., and O'Hara, P. D. (2011). Marine mammals and debris in coastal waters of British Columbia, Canada. Mar. Pollut. Bull. 62, 1303-1316. doi: 10.1016/j.marpolbul.2011.02.029

World Society for the Protection of Animals (WSPA) (2012). Marine Debris: A Global Picture of the Impact on Animal Welfare and of Animal-Focused Solutions, eds A. Butterworth, I. Clegg, and C. Bass (London: WSPA 
International). Available online at: http://oceansandplastics.info/wp-content/ uploads/2015/07/REP_WSPA_2012.pdf (Accessed June 27, 2016).

Zalasiewicz, J., Waters, C. N., Ivar do Sul, J. A., Corcoran, P. L., Barnosky, A. D., Cearreta, A., et al. (2016). The geological cycle of plastics and their use as a stratigraphic indicator of the Anthropocene. Anthropocene 13, 4-17. doi: 10.1016/j.ancene.2016.01.002

Zavala-González, A., and Mellink, E. (1997). Entanglement of California sea lions, Zalophus californianus californianus, in fishing gear in the central-northern part of the Gulf of California, Mexico. Fish. Bull. 95, 180-184.
Conflict of Interest Statement: The author declares that the research was conducted in the absence of any commercial or financial relationships that could be construed as a potential conflict of interest.

Copyright (c) 2016 Butterworth. This is an open-access article distributed under the terms of the Creative Commons Attribution License (CC BY). The use, distribution or reproduction in other forums is permitted, provided the original author(s) or licensor are credited and that the original publication in this journal is cited, in accordance with accepted academic practice. No use, distribution or reproduction is permitted which does not comply with these terms. 